UDC 543.1:541.3:547.442

\title{
SYNTHESIS AND STRUCTURE OF bis-[3-(FLUORPHENYLAZO- PENTADIENE-2,4)ETHYLENEDIIMINES] AND THE STUDY OF COMPLEX FORMATION WITH COPPER(II) ION
}

\author{
F.S.Aliyeva, F.O.Mamedova*, Y.E.Yusifov*, F.M.Chiragov \\ Baku State University \\ *Ganja State University
}

Farqana_chem@mail.ru

Received 07.06.2019

Accepted 14.10.2019

\begin{abstract}
Based on acetylacetone a new organic reagent was synthesized. Its crystal structure was studied. Its complexation with copper was Studied by spectrophotometric method. The effect of the third component on the complexation of $\mathrm{Cu}-\mathrm{R}$ was considered. The composition of the reactants was studied by different physico-chemical methods. The effect of foreign ions on complexation was studied. The technique was applied to the determination of trace amounts of copper in natural objects.
\end{abstract}

Keywords: extraction-photometric analysis, $\beta$-diketones, copper(II), complexation $\beta$-diketones, 3 (fluorophenylazo-pentadiene-2.4), bis[3-(fluorophenylazo-pentadiene-2.4)]ethylene diimine, X-ray structural analysis.

\section{doi.org/10.32737/0005-2531-2020-2-56-60}

Azo-compounds take a particular place among these reagents. In order to reduce the limit of analytical reactions and increase the selectivity they are passed through from binary to three-component systems. Therefore, the development of sensitive, selective, high-precision and rapid methods for the determination of copper(II) using azo compounds- modified forms of azo derivatives with $\beta$-diketones is an important task of analytical chemistry. It is known from literature that $\beta$-diketones and their derivatives are used for photometric and extraction-photometric determination of a number of metals [1-6]. These reagents are highly selective for the determination of $\mathrm{Cu}^{2+}, \mathrm{Fe}^{3+}$ and they are also used for group concentration of metals [7-12].

Therefore, the synthesis of new derivatives of $\beta$-diketones, the study their analytical capabilities are of great interest.

In this work, based on 3-(fluorophenylazo-pentadiene-2.4) a new reagent bis[3-(fluorophenylazo-pentadiene-2.4)]ethylenediimine was synthesized. Its crystal structure was determined.

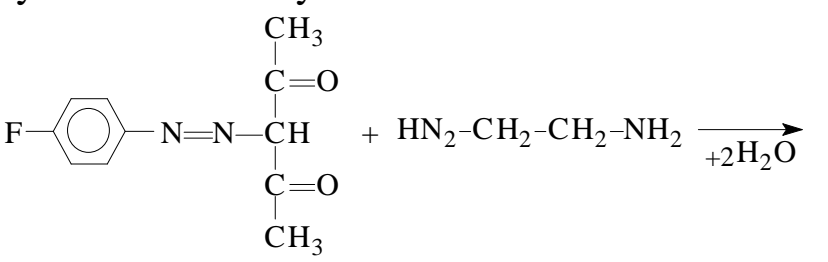

Its complex compounds with copper(II) ion were investigated by spectrophotometric method.

\section{Experimental part}

Equipment. The optical density of the solutions was measured on a Lambda- 40 spectrophotometer (Perkin Elmer) and a KFK-2 photocolorimeter in a cuvette with thickness of a layer $1 \mathrm{~cm}$. The $\mathrm{pH}$ of the solutions was controlled using a $\mathrm{pH}-25$ ionomer calibrated by standard buffer solutions.

X-ray diffraction analysis was performed on a Bruker SMART APEX II CCD automatic diffractometer $\left(\mathrm{M}_{0} K_{\alpha}\right.$-radiation, $\lambda=0.71073 \AA-$ on a graphite monochromator, $\varphi$ and $\omega-$ scanning).

Solutions and reagents. The initial reagent 3-(4-fluoro-pentadione-2,4) was synthesized according to a known method [13, 14]. bis[3(Fluorophenylazo-pentadiene-2.4)] ethylenediimine was synthesized according to the following scheme.<smiles>CC(=O)C(N=Nc1ccc(F)cc1)C(C)=NCCNC(C)C(C)C(N=Nc1ccc(F)cc1)C(C)=O</smiles> 
The reagent was synthesized according to the following procedure. $0.2 \mathrm{M}$ bis[3-(fluorophenylazo-pentadiene-2,4)] dissolved in 60 $\mathrm{ml}$ of ethanol was transferred into a conical flask and $0.1 \mathrm{M}$ ethylenediamine dissolved in $10 \mathrm{ml}$ of ethanol was added. The flask is attached to the reflux condenser. The mixture is stirred for 2 hours at $60^{\circ} \mathrm{C}$. The solution is left at room temperature. After a week, needleshaped red color crystals fall out from solution. The yield was $73 \%$.

The initial $\left(1 \cdot 10^{-3} \mathrm{M}\right)$ copper solution was prepared by dissolving the exact weighting of the analytical grade copper in concentrted. $\mathrm{HCl}$ at heating [15]. Working solutions with a lower copper content were prepared by diluting the stock solution with distilled water. The reagent is highly soluble in ethanol. $1 \cdot 10^{-3} \mathrm{M}$ reagent solution dissolved in ethanol, water-ethanol solution of $1 \cdot 10^{-2} \mathrm{M}$ phenanthroline, 2,2-dipyridyl and aqueous solution of ethylene diamine were used in the work.

\section{Results and discussion}

The structure of this compound was determined by X-ray diffraction analysis. The crystals are obtained with an orthorhombic structure: $a=18.9757$ (10) $\AA, b=10.7254$ (6) $\AA, c=$ 22.2875 (12) $\AA^{3}, Z=8$, Sp.g. $P_{2} / n$ (Figure 1 ).

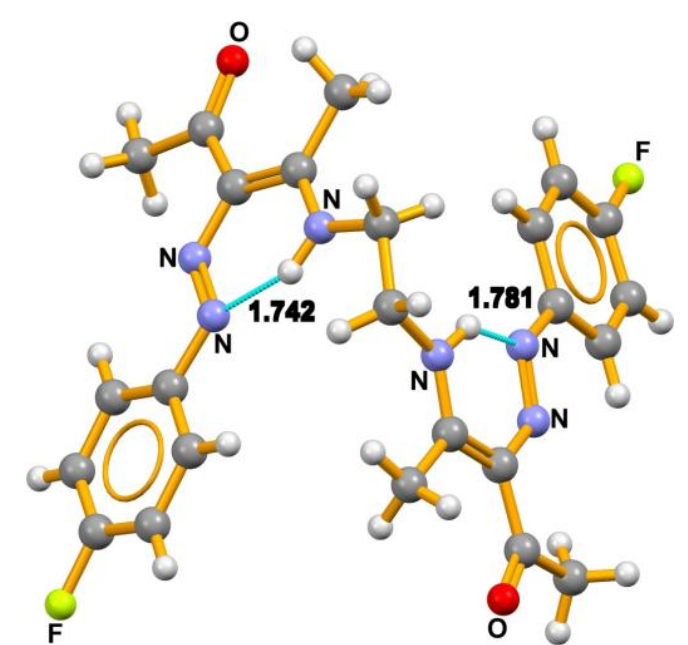

Fig. 1. The structure of the copper(II) complex.

The complex formation of copper with this reagent was studied by spectrophotometric method. Studied reagent formed a colored complex compound with copper ion. The maximum yield of the complex is observed at $\mathrm{pH} \mathrm{3,} \mathrm{the}$ optimal wavelength tape at $432 \mathrm{~nm}$. Under these conditions, the maximum light absorption of the reagent is observed at $348 \mathrm{~nm}$.

In the presence of the third component (2,2'-dipyridyl, $\alpha, \alpha^{\prime}$-phenanthroline, ethylenediamine) different ligand complexes of $\mathrm{Cu}$ (II)-R$\mathrm{T} / \mathrm{k}$ are formed, while bathochromic shifts are observed in the absorption spectra. Absorption of mixed ligand complexes $\mathrm{Cu}(\mathrm{II})-\mathrm{R}-2,2^{\prime}$-dipyridyl, $\mathrm{Cu}$ (II)-R-phen, $\mathrm{Cu}$ (II)-R-ED is maximum at 444,441 and $450 \mathrm{~nm}$, respectively. The study of the dependence of optical density on the $\mathrm{pH}$ of the solution showed that all the complexes are formed in an acidic medium at $\mathrm{pH}=2$. With the formation of mixed-ligand complexes, the output shifts into an acidic medium compared with the corresponding binary complexes (Figure 2). The color of the reagent and complexes depends on the $\mathrm{pH}$ of the medium, therefore, the absorption spectra under complexation were studied against the background of the control experiment. It was established that the optical density of binary mixed-ligand copper complexes is maximum at $440 \mathrm{~nm}$ (Figure 3).

To select the optimal conditions the effect of concentrations of initial substances, temperature and time on the formation of binary and mixed-ligand complexes has been studied. The output of the complexes $8 \cdot 10^{-5} \mathrm{M}$ MR; $\mathrm{Cu}$ (II)-RPhen $8 \cdot 10^{-5} \mathrm{M}$ MR and $4 \cdot 10^{-5} \mathrm{M}$ MR Phen, $\mathrm{Cu}$ (II) -R-2,2'-dip., $8 \cdot 10^{-5} \mathrm{M} \mathrm{R}$ and $4.8 \cdot 10^{-5} \mathrm{M}$ MR2,2'-dip, Cu-R-ED $8 \cdot 10^{-5} \mathrm{M}$ R and $4 \cdot 10^{-5} \mathrm{M}$ ED. All complexes are formed immediately after mixing the solutions of the components and differ in their stability. So if binary complexes are stable for two hours and when heated to $60^{\circ} \mathrm{C}$, then mixed-ligand complexes are stable for more than a day and when heated to $80^{\circ} \mathrm{C}$.

The ratio of components in the composition of the resulting complexes was established by the methods of isomolar series, the relative yield of the Starik-Barbanel, and the equilibrium shift.

The molar absorption coefficients of the complexes are calculated from the saturation curves. Concentration intervals have been established where Beer's law [16] is observed (Table 1). 


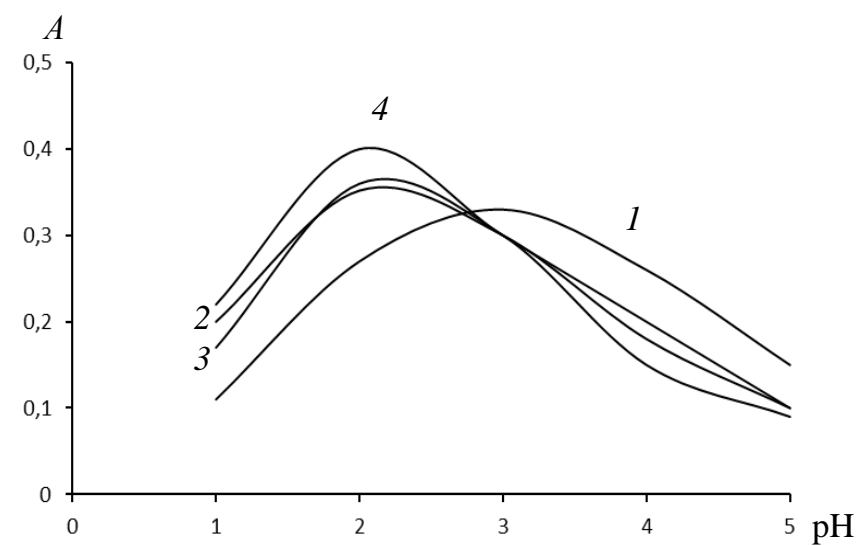

Fig. 2. Dependence of optical density of copper(II) solution complexes on $\mathrm{pH}$ in the presence and absence of third components at $\lambda_{\text {opt. }}$ on the background experience: 1 $\mathrm{Cu}-\mathrm{R} ; 2$ - Cu-R-Phen; 3 - Cu-R-2,2-dip; 4 - Cu-R-Ed. $C_{\mathrm{Cu}}=4 \cdot 10^{-5} \mathrm{M}, C_{\mathrm{R}}=8 \cdot 10^{-3} \mathrm{M}, \quad C_{\text {Phen,2,2-dip }}=8 \cdot 10^{-5} \mathrm{M}$, $C_{\mathrm{Ed}}=8 \cdot 10^{-4} \mathrm{M}, l=1 \mathrm{sm}$.

Table 1. The main characteristics of the photometric method determination of the copper(II) complexes

\begin{tabular}{|c|c|c|c|c|c|}
\hline Complex & 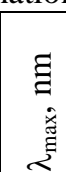 & $\frac{\alpha}{\ddot{d}}$ & 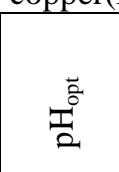 & 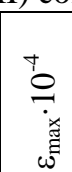 & $\begin{array}{c}\text { Submission } \\
\text { to the law of } \\
\text { Beer } \\
\mathrm{Cu} \mathrm{mg} / \mathrm{ml}\end{array}$ \\
\hline $\mathrm{Cu}-\mathrm{R}$ & 442 & $1: 1$ & 3 & 0.42 & $2.0-24$ \\
\hline $\mathrm{Cu}-\mathrm{R}-\mathrm{Phen}$ & 444 & $1: 1: 1$ & 2 & 0.48 & $2.0-25.6$ \\
\hline $\mathrm{Cu}-\mathrm{R}-2,2^{\prime}$-dip & 447 & $1: 1: 1$ & 2 & 0.47 & $1.8-25.6$ \\
\hline $\mathrm{Cu}-\mathrm{R}-\mathrm{ETD}$ & 452 & $1: 1: 1$ & 2 & 0.51 & $1.8-25.6$ \\
\hline OHT+anilin [9] & 660 & - & $3.6-5.4$ & 0.28 & $0.2-20$ \\
\hline
\end{tabular}

The study of the influence of foreign ions and masking substances on the complexation of copper in the form of binary and mixedligand complexes showed that in the presence of the third component, the selectivity of the reaction increases (Table 2).

The developed technique was applied to determine copper in copper-based alloys.

The course of the analysis. $0.2 \mathrm{~g}$ of the alloy is dissolved in $15 \mathrm{ml}$ of $\mathrm{HNO}_{3}(1: 1)$ when heated. The solution is transferred to a flask with a capacity of $100 \mathrm{ml}$ and diluted with distilled water to the mark. An aliquot portion of the solution is transferred to a $25 \mathrm{ml}$ flask, $2 \mathrm{ml}$ of $1 \cdot 10^{-3} \mathrm{M} \mathrm{R}$ and $1 \mathrm{ml}$ of $1 \cdot 10^{-2} \mathrm{M} \mathrm{R}$ of phenanthroline are added, diluted to the mark with

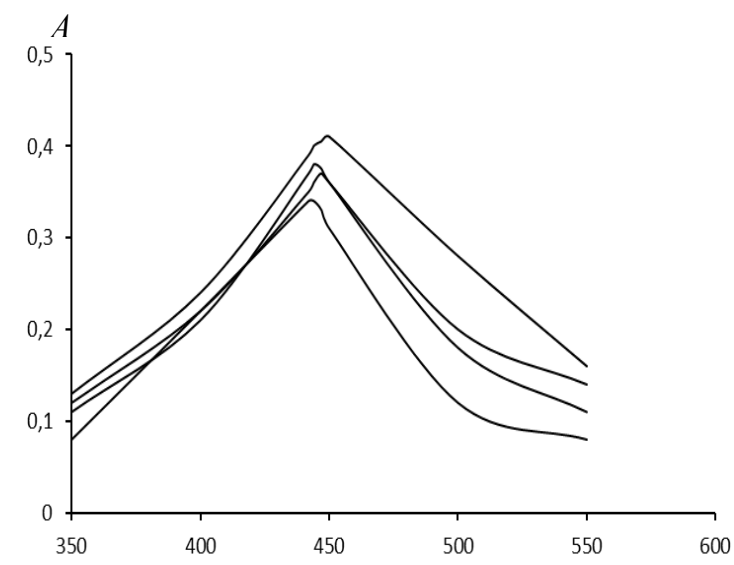

Fig. 3. Absorption spectra of copper(II) complexes: $1-$ $\mathrm{Cu}-\mathrm{R}, 2$ - Cu-R-Phen, 3 - Cu-R-2,2-dip, 4 - Cu-RETD. $C_{\mathrm{Cu}}=4 \cdot 10^{-5} \mathrm{M}, C_{\mathrm{R}}=8 \cdot 10^{-3} \mathrm{M}, C_{\text {Phen,2,2-dip }}=$ $8 \cdot 10^{-5} \mathrm{M}, C_{\mathrm{Ed}}=8 \cdot 10^{-4} \mathrm{M}, l=1 \mathrm{sm}$.

buffer $\mathrm{pH}$ 2. The optical density of the solution is measured on a KFK-2 spectrophotometer at $\lambda$ $=440 \mathrm{~nm}$ in cuvettes with a layer thickness of $l$ $=1 \mathrm{~cm}$. The results of the study are shown in Table 2.

Table 2. Copper definitions in copper based alloys $(n=5$, $P=0.95)$

\begin{tabular}{|c|c|c|c|c|}
\hline \multirow{2}{*}{ 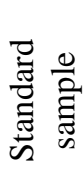 } & \multirow{2}{*}{ 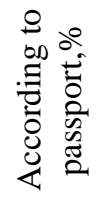 } & \multicolumn{2}{|c|}{ Found $\%$} & \multirow{2}{*}{$\mathrm{S}_{\mathrm{r}}$} \\
\hline & & $\begin{array}{l}\text { By electrograv- } \\
\text { imetric method }\end{array}$ & R-Phenantr. & \\
\hline 972 & 64.90 & 64.85 & 64.81 & 0.004 \\
\hline 973 & 64.01 & 63.94 & 63.95 & 0.003 \\
\hline 974 & 65.95 & 65.90 & 65.88 & 0.03 \\
\hline 975 & 61.52 & 61.50 & 61.47 & 0.04 \\
\hline
\end{tabular}

With large quantities of iron(III) (more than $30 \mathrm{mg}$ ) when determining copper it is masked with $5 \mathrm{ml}$ of $5 \% \mathrm{NH}_{4} \mathrm{~F}$. The remaining elements contained in the alloy do not interfere to the definition.

As can be seen from the Table 3, alkaline, alkaline-earth elements, REE(III), Co(II), $\mathrm{Cr}(\mathrm{III}), \mathrm{Cd}(\mathrm{II}), \mathrm{Th}(\mathrm{IV}), \mathrm{Zn}(\mathrm{II}), \mathrm{Pb}(\mathrm{II}), \mathrm{Bi}(\mathrm{III})$, $\mathrm{Be}(\mathrm{II}), \quad \mathrm{Al}(\mathrm{III}), \quad \mathrm{U}(\mathrm{VI}), \quad \mathrm{Mn}(\mathrm{II})$, halides, rhodanides, sulfates, sulfosalicylic and ascorbic acids practically do not interfere to the determination of copper. 
Table 3. Valid ratios of foreign ions on copper(II) at determination of it in the form of mono- and mixed-ligand complexes $\left(\mathrm{C}_{\mathrm{Cu}}=2 \cdot 10^{-5}\right.$, error $\left.5 \%\right)$.

\begin{tabular}{|c|c|c|c|c|c|c|}
\hline 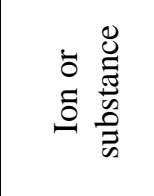 & $\simeq$ & 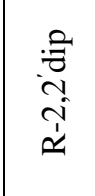 & $\frac{\frac{\pi}{2}}{\frac{2}{2}}$ & 至 & 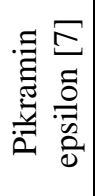 & 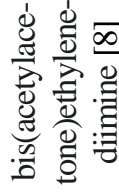 \\
\hline $\mathrm{Na}(\mathrm{I})$ & 2000 & 2450 & 2500 & & & 1796 \\
\hline $\mathrm{K}(\mathrm{I})$ & & & & & & 3046 \\
\hline $\mathrm{Ca}(\mathrm{II})$ & 380 & 700 & 760 & 780 & 20 & 312 \\
\hline $\mathrm{Ba}(\mathrm{II})$ & 800 & 1450 & 1465 & 1510 & & 642 \\
\hline $\mathrm{Zn}(\mathrm{II})$ & 710 & 1220 & 1250 & 1305 & 1500 & 508 \\
\hline $\mathrm{Cd}(\mathrm{II})$ & 920 & 1560 & 1560 & 1590 & 1000 & 875 \\
\hline $\mathrm{Mn}(\mathrm{II})$ & 90 & 120 & 120 & 140 & & 43 \\
\hline $\mathrm{Ni}(\mathrm{II})$ & 550 & 725 & 720 & 730 & 50 & 461 \\
\hline $\mathrm{Co}(\mathrm{II})$ & 380 & 450 & 465 & 476 & 100 & 276 \\
\hline $\mathrm{Al}(\mathrm{III})$ & 205 & 230 & 230 & 245 & 10 & 126 \\
\hline $\mathrm{Fe}(\mathrm{III})$ & 12 & 16 & 18 & 18 & & 9 \\
\hline $\mathrm{Ga}(\mathrm{III})$ & 88 & 110 & 125 & 120 & 60 & \\
\hline $\operatorname{In}(\mathrm{III})$ & 130 & 135 & 138 & 143 & & \\
\hline $\operatorname{Sn}(\mathrm{V})$ & 70 & 85 & 85 & 92 & & \\
\hline $\mathrm{Ti}(\mathrm{IV})$ & 110 & 125 & 130 & 130 & & \\
\hline Mo(IV) & 460 & 485 & 480 & 485 & 3 & 450 \\
\hline $\mathrm{W}(\mathrm{VI})$ & 430 & 480 & 498 & 505 & 100 & \\
\hline $\mathrm{C}_{2} \mathrm{O}_{4}{ }^{2-}$ & 140 & 170 & 185 & 180 & & 121 \\
\hline ЭДТА & 10 & 15 & 15 & 15 & & \\
\hline $\mathrm{F}^{-}$ & 60 & 75 & 80 & 80 & & 58 \\
\hline Thiourea & 180 & 205 & 210 & 220 & & \\
\hline Citric acid & 350 & 1600 & 1610 & 1610 & & \\
\hline $\mathrm{Na}_{2} \mathrm{HPO}_{4}$ & 1500 & 1720 & 1740 & 1730 & & \\
\hline Wine acid & 1700 & & & & & \\
\hline
\end{tabular}

\section{Conclusions}

1. To determine copper(II) by the photometric method, the azo-derivatives of $\beta$ diketones and their modified forms were used. The structure of the reagents was studied by NMR and IR spectroscopy, and the purity was verified by paper chromatography.

2. The structure of this compound was determined by the method of X-ray structural analysis.

3. Complex compounds of copper(II) with reagents were investigated by the spectrophotometric method, the optimal conditions of complexation and the characteristics of the complexes were determined $\left(\mathrm{pH}_{\mathrm{opt}}, \lambda_{\text {opt}}\right.$, molar absorption coefficients, the composition of the complexes, the interval of subordination to Beer's law, stability constant).
4. The effect of amines on the complex compounds of copper(II) with reagents was determined. It was determined that in the presence of the third component some analytical parameters of the reaction increase.

5. The effect of foreign ions and masking substances on complexation reactions was studied. It has been established that reactions with modified forms of reagents are characterized by higher selectivity.

6. The developed technique is applied to the determination of trace amounts of copper in natural objects.

\section{References}

1. Shawket K.Javad, Senaa K.Ali, Safa M.Hameed. Spectrophotometric determination of micro amount of copper(II) in different environmental and vital samples by new organic reagent. Iraqi National J. Chemistry. 2001. No 43. P. 299-309.

2. Shanthalakshmi K., Muraliahar Rao B. Spectrophotometric determination of copper using ovannillidine-2-amino-4-ethylbenzothiazoleas a chromogen icreagenic regent. Der Pharmacia Lettre 2015. V. 7. No 10. P. 281-284.

3. Khdeeja Jabbar Ali, Layla Ali Mohamed, Fatima Jabbar Ali, Haider Norri Raheem. New spectrophotometric determination of copper(II) using an organic reagent derived from imidazole and 4aminoantypyrine and applied onto different samples. J. Chem. and Pharmaceutical Sci. JCPS. 2015. V. 8. No 2. P. 201-207.

4. Orhan Turkoglu and Mustafa Soylak. Spectrophotometric determination of copper in natural waters and pharmaceutical samples with chloro(phenyl)glyoxime. J. Chinese Chem. Soc. 2005. V. 52. P. 575-579.

5. Archama R.Riacharecar, Thakkar N.V. Extractive spectrophotometric determination of copper(II) and its applications in pharmaceutical samples and alloys. J.Scientific \& Industrial Research. 2004. V. 63. No 3. P. 283-286.

6. Mahmudov K.T., Alieva R.A., Gadjieva S.R., Chiraqov F.M. Photometrik determination of copper (II) in nikel alloys using azoderivatives of ethilasetoasetat. J. Analyt. chem. 2008. 63. P. 435438.

7. Alieva R.A., Mahmudov K.T., Hasanov P.Q. Azoderivative of asetilasetone as a reagent for the photometric determination of lanthanum(III). Industrial laboratory. 2009. 75. No 2. P. 23-26.

8. Aliyeva R.A., Gambarov D.G., Chiragov F.M., Abdullaev R.A., Ayubova A.M., Babaev A.K. Extraction of metals by benzoylacetone derivatives. Bulletin BU. 1998.No 2. P. 21-24. 
9. Makhmudov K.T. Analytical research and use of copper complexes formed with azoderivatives of $\beta$-diketones. Thesis for the degree of candidate of chemical sciences. Baku: BGU. 2005. 214 p.

10. Dedkov Yu.M., Koluzanova V.P. Pikraminepsilov as a reagent for the photometric determination of copper(II). J. Analytical Chemistry. 1970. V. 25. No 8. P. 1482-1486.

11. Babayev A.K. Photometric determination of iron (III) in some related elements of $\beta$-diketones and their azomethine derivatives. Thesis for the degree of candidate of chemical sciences. Baku, 1982. $188 \mathrm{p}$.

12. Prassed N.B., Beddy Hussai. Simultaneous determination of copper(II) and nickel(II) using thio- semicarbazone and a - phenyl-1,2-propanedione2-oxime. Indian. Chem. Soc. 2007. 84. No 5. P. 474-477.

13. Busev A.I. Synthesis of new organic reagents for inorganic analysis. M: Moscow State University, 1972. P. 245.

14. Qambarov D.Q. A new class of photometric reagents is azocompounds on the base of pirogallole. Thesis for the degree of doctor of chemical sciences. M. 1984. 295 p.

15. Korostelev P.P. Preparation of solutions for chemical analytical work. M.: Science, 1964. P. 261.

16. Bulatov M.I., Kalinkin I.P. A practical guide to photometric and spectrophotometric method of analysis. L .: Chemistry, 1972. 407 p.

\section{bis[3-(FLÜORFENILAZO-PENTADIEN-2,4)] ETILENDIIMINIIN SINTEZI Və QURULUŞU, MİS İONLARI

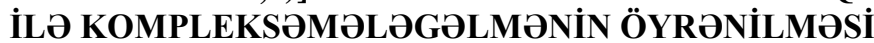

\section{F.S.Oliyeva, F.O.Məmmədova, Y.E.Yusifov, F.M.Çıraqov}

Asetilaseton əsasında yeni üzvi reagent sintez edilmişdir. Onların kristal quruluşları öyrənilmişdir. Spektrofotometrik metodla onların mislə kompleksəmələgətirməsi öyrənilmişdir. $\mathrm{Cu}-\mathrm{R}$ kompleksəmələgətirməsinə üçüncü komponentlərin təsiri öyrənilmişdir. Fiziki-kimyəvi metodlarla reaksiyaya girən maddələrin tərkibi müəyyənləşdirilmişdir. Kompleksəmələgəlməyə kənar ionların təsiri öyrənilmişdir. İşlənib hazırlanmış metodika mis saxlayan obyektlərdə misin mikromiqdarlarının təyini üçün tətbiq edilə bilər.

Açar sözlor: ekstraksion-fotometrik analiz, mis(II), $\beta$-diketonlar, 3-(flüorfenilazo-pentadien-2,4), bis[3-( flüorfenilazopentadien-2,4)]etilendiimin, rentgen struktur analiz.

\section{СИНТЕЗ И СТРОЕНИЕ бИС[3-(ФТОРФЕНИЛАЗО-ПЕНТАДИЕН-2,4) ЭТИЛЕНДИИМИНОВ] И ИЗУЧЕНИЕ КОМПЛЕКСООБРАЗОВАНИЕ С ИОНОМ МЕДИ(ІІ)}

\section{Ф.С.Алиева, Ф.О.Мамедова, Ю.Е.Юсифов, Ф.М.Чырагов}

На основе ацетилацетона синтезирован новый органический реагент. Изучена его кристаллическая структура. Спектрофотометрическим методом изучено его комплексообразование с $\mathrm{Cu}(\mathrm{II})$ ионом. Рассмотрено влияние третьего компонента на комплексообразование $\mathrm{Cu}-\mathrm{R}$. Разными физикохимическими методами изучен состав полученного вещества. Показано влияние посторонних ионов на комплексообразование. Разработанная методика рекомендована для определения микроколичеств меди в медьсодержащих объектах.

Ключевые слова: экстракциионно-фотометрический анализ, медь(II), $\beta$-дикетоны, 3-(фторфенилазопентадиен-2,4), бис[3-(фторфенилазо-пентадиен-2,4)]этилендиимин, рентгеноструктурный анализ. 